\title{
An Investigation of Classroom Management Strategy ( A Case Study of Tenth Grade English Teachers at SMAN 2 Kota Bengkulu)
}

\author{
Dona Novianti Ulfa \\ English Education Study Program, Department of Language and Art \\ University of Bengkulu \\ dona.noviantiulfa@yahoo.com

\section{Rudi Afriazi} \\ English Education Study Program, Department of Language and Art \\ University of Bengkulu \\ rudiafriazi88@gmail.com

\section{Elfrida} \\ English Education Study Program, Department of Language and Art \\ Universitas Bengkulu \\ mrs.elfrida@gmail.com
}

\begin{abstract}
The objective of this research was to find out the classroom management strategies implemented by the English teachers and the reason in applying the most often strategy than others strategies. This study employed the descriptive qualitative method, the subject of the research were the English teachers (2 persons) at SMAN 2 Kota Bengkulu.. The data was collected by using observations checklist and interview. The result of the research revealed there are 5 strategies used by the teachers in managing the classroom; 1) Strategies to arrange the classroom, 2) Strategies to build positive relation with the student, 3) Strategies to create positive classroom environment, 4) Strategies to prevent misbehavior and 5) Strategies to handle the students' discipline situation. In 5 meetings the total aspects of the first strategy applied by the teacher 1 and teacher 2 was about 33 and 37. The second strategy was 30 and 31 . The third strategy was 26 and 24 . The fourth strategy was 25 and 28 . The last strategy was 25 and 24. Furthermore, the reasons of why the teachers applying the most often strategy than others strategies because it helps the teachers in the teaching and learning process to be more conducive. Beside that the strategies also help the teachers to create an effective

teaching and learning process. Therefore, it could be concluded that the English teachers of SMAN 2 Kota Bengkulu used all the 5 strategies as mentioned by Marzano (2003) in managing classroom but not all aspects they used in teaching and learning process. The dominant strategy implemented by Teacher I and Teacher 2 were strategy to arrange the classroom. Meanwhile, the least strategy implemented by both teachers were the strategy to handle the students discipline situation.
\end{abstract}

Keywords: Classroom Management Strategy, English Teacher 


\title{
Journal of English Education and Teaching \\ Volume 3 number 22019
}

Pp. 156-170

\begin{abstract}
ABSTRAK
Tujuan dari penelitian ini adalah untuk mengetahui strategi manajemen kelas yangditerapkan oleh guru bahasa Inggris dan alasan dalam menerapkan strategi yang paling sering daripada strategi lain. Penelitian ini menggunakan metode deskriptif kualitatif, subjek penelitian adalah guru Bahasa Inggris (2 orang) di SMAN 2 Kota Bengkulu. Data dikumpulkan dengan menggunakan daftar observasi dan wawancara. Hasil penelitian mengungkapkan ada 5 strategi yang digunakan oleh guru dalam mengelola kelas; 1) Strategi untuk mengatur ruang kelas, 2) Strategi untuk membangun hubungan positif dengan siswa, 3) Strategi untuk menciptakan lingkungan kelas yang positif, 4) Strategi untuk mencegah perilaku buruk dan 5) Strategi untuk menangani situasi kedisiplinan siswa. Dalam 5 pertemuan total aspek dari strategi pertama yang diterapkan oleh guru 1 dan guru 2 adalah sekitar 33 dan 37 . Strategi kedua adalah 30 dan 31. Strategi ketiga adalah 26 dan 24. Strategi keempat adalah 25 dan 28. Strategi terakhir adalah 25 dan 28. strategi adalah 25 dan 24. Selanjutnya, alasan mengapa para guru menerapkan strategi yang paling sering daripada strategi lain karena itu membantu para guru dalam proses belajar mengajar menjadi lebih kondusif. Selain itu strategi juga membantu para guru untuk menciptakan proses belajar mengajar yang efektif. Oleh karena itu, dapat disimpulkan bahwa guru bahasa Inggris SMAN 2 Kota Bengkulu menggunakan semua 5 strategi sebagaimana disebutkan oleh Marzano (2003) dalam mengelola kelas tetapi tidak semua aspek yang mereka gunakan dalam proses belajar mengajar. Strategi dominan yang diterapkan oleh Guru I dan Guru 2 adalah strategi untuk mengatur kelas. Sementara itu, strategi yang paling tidak diterapkan oleh kedua guru adalah strategi untuk menangani situasi disiplin siswa.
\end{abstract}

Kata kunci: Guru Bahasa Inggris, Strategi Manajemen Kelas.

\section{Introduction}

Teaching is the way to convey information about a topic that would be learned by the students. The purpose of the teaching and learning process is to make students get knowledge and able to understand the knowledge. To achieve the purpose of teaching, the teacher is as a key that should be creative in choosing the materials and strategies of teaching to make the students easy to understand the knowldege.

One of the most important skills that teachers should have in teaching and learning process is the ability to manage the classroom. Marzano (2003), stated that the most important role of teachers among 
the other roles is as a manager. Teachers should be able to manage classes well and provide conditions that enable students to learn in order to obtain the expected results. If teachers cannot properly manage the classrooms, teaching and learning process would not run effectivelly.

Classroom management is an effort made by the teacher in the classroom to create a conducive, comfortable, and plesant atmosphere in the classroom. According to Sagala(2000), classroom management activities is not a simple activity or routine that can be done at random to be dealt with seriously. Therefore, to bolster its ability in managing learning, teachers must understand the aspect contained in classroom management as well skilled in implementing them in the classroom.

The teachers need strategy to conduct the teaching and learning process succesfully. The strategy is very decisive because it is the way of the teachers to conduct an activity in order to reach the objectives of the learning process. The teaching strategy will help the teachers to get the goal of the teaching and learning process effectively. (McCreary, 2011) stated that the classroom management strategy is defined as the method and strategy that educators use to maintain a conducive classroom environment for students' successfully learning.

Managing the classroom is still considered for some English teachers and teachers trainees difficult to conduct. They may lack of strategies to manage the classroom. For the teacher who have limited experience and strategy, classroom management is very hard to conduct. Futhermore based on the researcher experienced when teaching practice, the researcher found there are so many difficulties when the researcher wanted manage the classroom.

There was some reasons why the researcher choose this topic. First, the researcher found difficulties in managing the classroom that considered by the teachers and the teacher trainees is being the main reason. The second, the researcher and the teacher trainees need to know about the appropriate strategies in managing the classroom. The third, teachers' strategies must create the classroom environment to be conducive to support the teaching and learning process. The last reason is 
this research can provide the information to the UPPL University of Bengkulu as the cope institution of the teacher trainees. It can be used for them as the field data about the ability of the teachers in managing the classroom.

SMAN 02 Kota Bengkulu will become the subject in this research. The reason why the researcher conduct this research at this school that's a favorite school in Bengkulu city. In addition, the researcher has observed the teachers in the teaching and learning process. The classroom situation were conducive when the teachers were teaching in the classroom. Basically students at SMAN 2 Kota Bengkulu were already disciplined in any way.

Based on the reasons above, it is important to know the teachers strategy in the classroom management. Researching teachers' strategy in classroom management at this school may reflect the strategies that are applied by English teachers at the senior high school in Bengkulu. The researcher entitled this research: An Investigation of Classroom Management Strategy (A case Study of Tenth Grade English Teachers at SMAN 02 Kota Bengkulu).

\section{Method}

In this research the researcher used descriptive qualitative research. Qualitative is used to investigate a problem in order to get clear understanding of certain phenomenon (Cresswell, 2012). sample in this research, there were 2 English teachers who were willing to be investigated of SMAN 02 Kota Bengkulu. The teachers was observed in this research were Mr. Suciya (Class X IPS) and Mrs. Amelia (Class X MIPA). These 2 English teachers investigated about their strategies in managing the classroom. Futhermore, SMAN 02 Kota Bengkulu was selected because this school was categorized as a favourite school in Bengkulu. Based on pre-survey at this school, the classroom was conducive when teaching and learning process occured.

In this research, the researcher used observations checklist and interview as the instrument. Observation checklist was one of the informal 
method of observation where the observer had set behavioral indicators that were in observation of the subject in one table. The observation checklist was made by the researcher to guide when observing the classroom. Second, The researcher interviewed the teachers to complete the data about the teachers' strategies in managing the classroom. This interview was conducted after the observation.

\section{Result and Discussion}

\section{The Result of Observation}

Based on the result of observation. The result here discussed by presenting the data from observations checklist and the data from interviews. The result showed the English teachers used strategies in classroom management at SMAN 2 Kota Bengkulu based on the aspects of the strategies.. These all table from 5 strategies:

\begin{tabular}{|c|c|c|c|}
\hline \multirow[t]{2}{*}{ No } & \multirow[t]{2}{*}{ Strategies } & \multicolumn{2}{|c|}{ Percentage } \\
\hline & & Teacher 1 & Teacher 2 \\
\hline 1. & Strategies to arrange the classroom & $82 \%$ & $92 \%$ \\
\hline 2. & Strategies to build positive relation with the student & $75 \%$ & $77 \%$ \\
\hline 3. & $\begin{array}{l}\text { Strategies to create positive classroom } \\
\text { environment }\end{array}$ & $65 \%$ & $60 \%$ \\
\hline 4. & Strategies to prevent misbehavior & $62 \%$ & $70 \%$ \\
\hline 5. & $\begin{array}{l}\text { Strategies to handle the students' discipline } \\
\text { situation }\end{array}$ & $62 \%$ & $60 \%$ \\
\hline & Average & $70 \%$ & $71 \%$ \\
\hline
\end{tabular}




\section{Strategies to Arrange The Classroom}

The teachers' implementation of this strategy was shown in this table.

Table 1. Strategies to Arrange the Classroom

\begin{tabular}{|c|c|c|c|c|c|}
\hline \multirow[t]{2}{*}{ No } & \multirow[t]{2}{*}{ Aspects } & \multicolumn{2}{|c|}{ Teacher 1} & \multicolumn{2}{|c|}{ Teacher 2} \\
\hline & & Yes & Percentage & Yes & Percentage \\
\hline 1 & $\begin{array}{l}\text { The teacher should be able to } \\
\text { observe all students in the class }\end{array}$ & 5 & $100 \%$ & 5 & $100 \%$ \\
\hline 2 & $\begin{array}{l}\text { The teacher provide a neat and } \\
\text { organized classroom to the } \\
\text { students }\end{array}$ & 5 & $100 \%$ & 5 & $100 \%$ \\
\hline 3 & $\begin{array}{l}\text { The teacher make the classroom } \\
\text { fun, attractive, motivating and } \\
\text { functional. }\end{array}$ & 5 & $100 \%$ & 5 & $100 \%$ \\
\hline 4 & $\begin{array}{l}\text { The students should be able to } \\
\text { see the teacher }\end{array}$ & 5 & $100 \%$ & 5 & $100 \%$ \\
\hline 5 & $\begin{array}{l}\text { Structure the classroom to avoid } \\
\text { chaos }\end{array}$ & 3 & $60 \%$ & 5 & $100 \%$ \\
\hline 6 & $\begin{array}{l}\text { The classroom should have own } \\
\text { equipments, so the students will } \\
\text { not disturb each other (i.e. pen, } \\
\text { pencil, or erases at the teachers' } \\
\text { table) }\end{array}$ & 4 & $80 \%$ & 5 & $100 \%$ \\
\hline 7 & The classroom look attractive & 4 & $40 \%$ & 4 & $80 \%$ \\
\hline 8 & $\begin{array}{l}\text { The teacher arrange the } \\
\text { classroom to allow easy } \\
\text { movement }\end{array}$ & 2 & $40 \%$ & 3 & $60 \%$ \\
\hline & Total & 33 & $82 \%$ & 37 & $92 \%$ \\
\hline
\end{tabular}

Based on the result of the observation done by researcher, 5 of 8 aspects were reached $100 \%$ for both teacher where they often used these 5 aspects, they were point 1 to 5 . There were 3 aspects that they have differences in arranging the classroom. They were point 6 to 8 . For the lowest aspects used by the both teacher was aspects in point 8 , it was $40 \%$ and $60 \%$. Total percentage of strategy used by teacher 1 was about $82 \%$ or 33 and teacher 2 was about $92 \%$ or 37 . 


\section{Strategies to Build Positive Relation with the Students}

The teacher's implementation of this strategy was shown in this table.

Table 2. Strategies to Build Positive with Students

\begin{tabular}{|c|c|c|c|c|c|}
\hline \multirow[t]{2}{*}{ No } & \multirow[t]{2}{*}{ Aspects } & \multicolumn{2}{|c|}{ Teacher 1} & \multicolumn{2}{|c|}{ Teacher 2} \\
\hline & & Yes & Percentage & Yes & Percentage \\
\hline 1 & $\begin{array}{l}\text { The teacher treat all the students } \\
\text { with respect and kindness }\end{array}$ & 5 & $100 \%$ & 5 & $100 \%$ \\
\hline 2 & $\begin{array}{l}\text { The teacher talk with the } \\
\text { students before and after the } \\
\text { class }\end{array}$ & 5 & $100 \%$ & 5 & $100 \%$ \\
\hline 3 & $\begin{array}{l}\text { The teacher praises the students } \\
\text { for good work }\end{array}$ & 4 & $80 \%$ & 5 & $100 \%$ \\
\hline 4 & $\begin{array}{l}\text { The teacher praises the students } \\
\text { for effort }\end{array}$ & 4 & $80 \%$ & 4 & $80 \%$ \\
\hline 5 & $\begin{array}{l}\text { The teacher establishes } \\
\text { appropriate levels of dominance } \\
\text { and cooperation }\end{array}$ & 3 & $60 \%$ & 4 & $80 \%$ \\
\hline 6 & $\begin{array}{l}\text { The teacher identifies a few } \\
\text { students in each class period } \\
\text { and find ways to individually } \\
\text { praise them }\end{array}$ & 3 & $60 \%$ & 3 & $60 \%$ \\
\hline 7 & $\begin{array}{l}\text { The teacher creates one to one } \\
\text { interactions with the students }\end{array}$ & 3 & $60 \%$ & 3 & $60 \%$ \\
\hline 8 & $\begin{array}{l}\text { The teacher displays the } \\
\text { students' succesful work in the } \\
\text { classroom }\end{array}$ & 3 & $60 \%$ & 2 & $60 \%$ \\
\hline & Total & 30 & $75 \%$ & 31 & $77 \%$ \\
\hline
\end{tabular}

Based on the result of the observation done by the researcher, 2 of 8 aspects were reached $100 \%$ for both teacher where they often used these 5 aspects, they were point 1 and 2. But there were 6 aspects that they have differences in build positive relation with the students. They were point 3 to 8 . For the lowest aspects used by the both teacher was aspects in point 8 , it was $60 \%$. Total percentage of strategy used by teacher 1 was about $75 \%$ or 30 and teacher 2 was about $77 \%$ or 31 . 


\section{Strategies to Create Positive Classroom Environment}

The teacher's implementation of this strategy was shown in this table.

Table 3. Strategies to Create Positive Classroom Environment

\begin{tabular}{|c|c|c|c|c|c|}
\hline \multirow[t]{2}{*}{ No } & \multirow[t]{2}{*}{ Aspects } & \multicolumn{2}{|c|}{ Teacher 1} & \multicolumn{2}{|c|}{ Teacher 2} \\
\hline & & Yes & Percentage & Yes & Percentage \\
\hline 1 & The teacher shows enthusias & 5 & $100 \%$ & 5 & $100 \%$ \\
\hline 2 & $\begin{array}{l}\text { The teacher good listening skill } \\
\text { by paying attention when } \\
\text { student speak }\end{array}$ & 5 & $100 \%$ & 5 & $100 \%$ \\
\hline 3 & The teacher uses humor & 5 & $100 \%$ & 4 & $80 \%$ \\
\hline 4 & $\begin{array}{l}\text { The teacher provides } \\
\text { oppurtunities for every student }\end{array}$ & 4 & $80 \%$ & 3 & $60 \%$ \\
\hline 5 & $\begin{array}{l}\text { The teacher greets the students } \\
\text { at the doorway }\end{array}$ & 3 & $60 \%$ & 4 & $80 \%$ \\
\hline 6 & $\begin{array}{l}\text { The teacher creates anticipation } \\
\text { for lessons or tasks }\end{array}$ & 4 & $80 \%$ & 3 & $60 \%$ \\
\hline 7 & $\begin{array}{l}\text { The teacher creates classroom } \\
\text { rituals and traditions which build } \\
\text { a sense of community }\end{array}$ & 0 & - & 0 & - \\
\hline 8 & $\begin{array}{l}\text { The teacher encourages } \\
\text { parental and community } \\
\text { involvement }\end{array}$ & 0 & - & 0 & - \\
\hline & Total & 26 & $65 \%$ & 24 & $60 \%$ \\
\hline
\end{tabular}

Based on the result of the observation done by the researcher, 3 of 8 aspects were reached $100 \%$ for teacher 1 where she often used these 5 aspects, they were point 1, 2 and 3 . Teacher 2 did 2 of 8 aspects were reached $100 \%$ where he often used these 5 aspects, they were point 1 and 2. But there were 6 aspects that they have differences. They were point 3 to 8 . For the lowest aspects used by the both teacher were aspects in point 7 and 8 were $0 \%$. Total percentage of strategy used by teacher 1 was about $65 \%$ or 26 and teacher 2 was about $60 \%$ or 24 . 


\section{Strategies to Prevent Misbehavior}

The teacher's implementation of this strategy was shown in this table.

Table 4. Strategies to Prevent Misbehavior

\begin{tabular}{|c|c|c|c|c|c|}
\hline \multirow[t]{2}{*}{ No } & \multirow[t]{2}{*}{ Aspects } & \multicolumn{2}{|c|}{ Teacher 1} & \multicolumn{2}{|c|}{ Teacher 2} \\
\hline & & Yes & Percentage & Yes & Percentage \\
\hline 1 & $\begin{array}{l}\text { The teacher establishes realistic } \\
\text { and age appropriate rules and } \\
\text { procedures }\end{array}$ & 4 & $80 \%$ & 5 & $100 \%$ \\
\hline 2 & $\begin{array}{l}\text { The teacher have discussions } \\
\text { with students about the rationale } \\
\text { and purpose of each rule. }\end{array}$ & 5 & $100 \%$ & 4 & $80 \%$ \\
\hline 3 & $\begin{array}{l}\text { The teacher walk throughout the } \\
\text { students seat during lectures and } \\
\text { to provide assistance and } \\
\text { monitor behavior }\end{array}$ & 5 & $100 \%$ & 4 & $80 \%$ \\
\hline 4 & $\begin{array}{l}\text { The teacher keep class work and } \\
\text { assigments separate from } \\
\text { behaviour issues }\end{array}$ & 5 & $100 \%$ & 5 & $100 \%$ \\
\hline 5 & $\begin{array}{l}\text { The teacher carefully plan each } \\
\text { class time and has extra plans in } \\
\text { case finish early }\end{array}$ & 4 & $80 \%$ & 3 & $60 \%$ \\
\hline 6 & $\begin{array}{l}\text { The teacher has extra activities } \\
\text { available for students to do } \\
\text { when they are bored or finished } \\
\text { with all their work }\end{array}$ & 2 & $40 \%$ & 2 & $40 \%$ \\
\hline 7 & $\begin{array}{l}\text { The teacher establishes routines } \\
\text { for transitions and prepares } \\
\text { students for transitions by } \\
\text { warning them ahead of time }\end{array}$ & 0 & - & 0 & - \\
\hline 8 & $\begin{array}{l}\text { The teacher reinforce and praise } \\
\text { appropriate behavior }\end{array}$ & 2 & $40 \%$ & 5 & $100 \%$ \\
\hline & Total & 25 & $62 \%$ & 28 & $70 \%$ \\
\hline
\end{tabular}

Based on the result of the observation done by the researcher, 3 of 8 aspects were reached $100 \%$ for teacher 1 where she often used these 5 aspects, they were point 2, 3 and 4 . Teacher 2 did 3 of 8 aspects were 
reached $100 \%$ where he often used these 5 aspects, they were point 1,4 and 8 . For the lowest aspects used by the both teacher were aspects in point 7 was $0 \%$. Total percentage of strategy used by teacher 1 was about $62 \%$ or 25 and teacher 2 was about $70 \%$ or 28 .

\section{Strategies to Handle The Student's Discipline Situation}

The teacher's implementation of this strategy was show in this table.

Table 5. Strategies to handle the Student's Discipline Situation

\begin{tabular}{|c|c|c|c|c|c|}
\hline \multirow[t]{2}{*}{ No } & \multirow[t]{2}{*}{ Aspects } & \multicolumn{2}{|c|}{ Teacher 1} & \multicolumn{2}{|c|}{ Teacher 2} \\
\hline & & Yes & Percentage & Yes & Percentage \\
\hline 1 & $\begin{array}{l}\text { The teacher when correcting } \\
\text { misbehaviour, communicates in } \\
\text { the most private, respectful, and } \\
\text { positive manner }\end{array}$ & 4 & $80 \%$ & 4 & $80 \%$ \\
\hline 2 & $\begin{array}{l}\text { The teacher makes all discipline } \\
\text { decisions after the "heat of the } \\
\text { moment }\end{array}$ & 4 & $80 \%$ & 3 & $60 \%$ \\
\hline 3 & $\begin{array}{l}\text { The teacher uses appropriate } \\
\text { humor to de-esclate conflict } \\
\text { situations }\end{array}$ & 5 & $100 \%$ & 4 & $80 \%$ \\
\hline 4 & $\begin{array}{l}\text { The teacher when she feel as if } \\
\text { she or her student is too } \\
\text { emotional to handle a particular } \\
\text { situation. }\end{array}$ & 2 & $40 \%$ & 1 & $20 \%$ \\
\hline 5 & $\begin{array}{l}\text { The teacher instead of blaming, } \\
\text { use I-messages to explain why } \\
\text { the behaviour was disruptive. }\end{array}$ & 2 & $40 \%$ & 4 & $80 \%$ \\
\hline 6 & $\begin{array}{l}\text { The teacher uses positive self-talk } \\
\text { to reduce stress and help to } \\
\text { remain control. }\end{array}$ & 4 & $80 \%$ & 5 & $100 \%$ \\
\hline 7 & $\begin{array}{l}\text { The teacher attempt to de- } \\
\text { escalate situation by providing } \\
\text { distractions. }\end{array}$ & 4 & $80 \%$ & 3 & $60 \%$ \\
\hline 8 & $\begin{array}{l}\text { The teacher exaggerate } \\
\text { problems to help students put } \\
\text { the situation in their view point }\end{array}$ & 0 & - & 0 & - \\
\hline & Total & 25 & $62 \%$ & 24 & $60 \%$ \\
\hline
\end{tabular}


Based on the result of the observation done by the researcher, 1 of 8 aspects was reached $100 \%$ for teacher 1 where she often used these 5 aspects, they were point 3, the teacher always used appropriate humor to de-esclate conflict situations. Teacher 2 did 1 of 8 aspects were reached $100 \%$ where he often used these 5 aspects, they were point 6 . For the lowest aspects used by the both teacher were aspects in point 8 were 0 \%. Total percentage of strategy used by teacher 1 was about $62 \%$ or 25 and total percentage of teacher 2 was about $60 \%$ or 24 .

\section{Result of Interview with the Teachers}

Based on the interviews, Why teacher 1 used the strategy arranging the classroom much more often than other strategies in classroom management, the teacher 1 explained that so many immediate benefits of a well organized classroom to the teacher such as less wasted time and therefore more efficient.

This strategy made the teacher try to created the classroom more attractive and conducive. The students could respected each other and created clean and comfortable class for them to learned, so many benefits from this strategy to made the teaching and learning process run well.

Teacher 2 explains that organized the classrooms could maximized the instruction to students, met the needs of social interaction, and provided an organized and efficient learning environment. In this strategy, the teacher made the classroom fun, interesting, motivational and functional, students become interested in the teaching and learning process and in this way could produced these students became more creative and innovative. Therefore, this strategy was the most important strategy to used.

\section{Discussion}

The first finding in this study was find out the highest score of strategy that the most often used by the English teachers at SMA 2 Kota Bengkulu. The result of this research, the most often strategy used by both of teacher were strategies to arrange the classroom. The lowest aspect of teachers used in point 8 , the teachers does not need to be arranged, the 
conventional seat have support the teaching and learning process. This strategy was highest score because both of teacher expected that this strategy was the most important thing to make the teaching and learning process run well. This strategy included a very good strategy because the percentage of results was the highest than other strategies.

The second finding in this study was the reasons of why the teachers applied the a strategy the most often than others strategies, because it helps the teachers in the teaching and learning process and provides the class to be more conducive. This strategy make teacher must work to have an attractive and fun. The students could appreciate and enjoy as well as creating a comfortable room for them to learn, so many good effect from this strategy to make teaching and learning process run well. Therefore, it could be concluded that the English teachers of SMAN 2 Kota Bengkulu used all the 5 strategies as mentioned by Marzano (2003) in managing classroom but not all aspects they used in teaching and learning process.

Moreover, The previous study by Indri (2017), the first component of the class management process was the physical design of the class. According to her observations, the teacher applied various seating arrangements depended on the activity. The teacher arranged seating in a regular row when the teacher explained the material used the board. Compare with this research, it was as well as the teachers at SMAN 2 Kota Bengkulu used the strategies to arrange the classroom as the most important component in classroom management.

Another study conducted by Rudiyanto (2014), the English teachers at SMPN 3 Tengaran gave punishment to the students who did not pay attention to the lesson by gave warn that the teacher would reduce their score. It can be concluded that the teacher seemed to try to overcome the deviant behavior of students., but the students of SMAN 2 Kota Bengkulu were already disciplined in any way. The teachers also respectful when corrected the misbehavior.

Therefore, it could be concluded that the English teachers of SMAN 2 Kota Bengkulu used all the 5 strategies as mentioned by Marzano 
(2003) in managing classroom but not all aspects they used in teaching and learning process.

\section{Conclusion and Suggestion}

\section{Conclusion}

Based on the previous research and discusssion the researcher finally could get the conclusions of the research which were the English teachers of SMAN 2 Kota Bengkulu used 5 strategies in managing the classroom, there were strategy to arrange the classroom, strategy to build the positive relationships with students, strategy to creating a positive classroom environment, strategy to prevent students' misbehavior and strategy to handle the student discipline situation. The most often strategy applied by Teacher I and Teacher 2 were strategy to arrange the classroom and the least strategy applied by them were strategy to handle the student discipline situationthe reasons of why the teachers applying the most often strategy than others strategies because it helps the teachers in the teaching and learning process to be more conducive. Beside that the strategies also help the teachers to create an effective teaching and learning process. 2. The reasons of why the teachers apply the most often strategy used than other strategies because it helps the teachers in the teaching and learning process to be more conducive, motivated and effective. Beside the strategies also help the teachers to create an effective teaching and learning process.

\section{Suggestion}

Based on the the result of the conducted research, the researcher would like to present the following suggestions. First, for English teachers, they must often implement classroom management, especially on strategies that were not commonly used in the strategy to handle the students' discipline situation. Second, for other teachers of SMAN 2 Kota Bengkulu suggested this study was expected to be a reference to implement classroom management strategy. Also the results of this research were expected to be source of ideas for the development of research in the future. Last, for further researchers, several theories of this 
research could be compared with other classroom management to make this research broader.

\section{References}

Creswell, J. 2012. Educational research (4th ed). Boston:

Pearson Education.

Indri. 2017. Classroom Management Applied in Teaching English by The Tenth

Grade English Teacher of SMA N 1 Wonosari in the Academic Year of 2015/2016. The State Islamic Institute of Surakarta. Surakarta.

Marzano, Jana S. \& Debra Pickering. 2003. Classroom Management Thats Works: Researchbased Strategies for Every Teacher. ASDC.

McCreary. 2013. Classroom Management. In EHow. Retrieved February 26, 2013. (www.ehow.com/about 5438989 classroommanagementdefinition.html )

Rudiyanto, Arif. 2014. Descriptive Analysis of Classroom Management Strategies of the Second Grade Students of SMP N 03 Tengaran Semarang. STAIN Salatiga (Unpublished S1 thesis).STAIN University, Semarang, Indonesia.

Sagala, Syaiful. 2000. Administrasi Pendidikan Kontenporer. Bandung: CV. Alfabeta.

\section{Writer Information}

\begin{tabular}{|l|l|}
\hline Name & Dona Novianti Ulfa \\
\hline Affiliation & $\begin{array}{l}\text { English Education Study Program, Department of } \\
\text { Language and Art, University of Bengkulu }\end{array}$ \\
\hline Email & dona.noviantiulfa@yahoo.com \\
\hline Phone Number & 085217193062 \\
\hline
\end{tabular}


Journal of English Education and Teaching

Volume 3 number 22019

Pp. 156-170 